\title{
HUBUNGAN ANTARA LAMA PEMAKAIAN KB SUNTIK DMPA DENGAN TIMBULNYA EFEK SAMPING PADA AKSEPTOR KB DI PMB HENRY WULANDARI, A.Md Keb DESA ANTIROGO KABUPATEN JEMBER
}

\author{
Dewi Rakhmawati \\ Akademi Kebidanan Bina Husada Jember \\ Email:drakhma23@yahoo.com
}

\begin{abstract}
Abstrak
Efek samping dari akseptor KB suntik berupa gangguan haid, depresi, rambut rontok, jerawat, perubahan libido, keputihan, mual muntah, pusing, perubahan berat badan, salah satu penyebabnya adalah lamanya pemakaian. Hal itu dapat berdampak pada gangguan hormonal, gangguan tingkat kesuburan, penumpukan kolesterol akibat timbunan lemak, infeksi, perdarahan vaginal yang berat, keputihan berlebih, klien drop out dari KB suntik. Penelitian ini bertujuan mengetahui adanya hubungan antara lama pemakaian kontrasepsi suntik Depo Medroksiprogesterone acetate (DMPA) dengan timbulnya efek samping pada akseptor KB. Jenis penelitian ini analitik korelasional dengan rancangan cross sectional. Sampel penelitian ini adalah akseptor kontrasepsi suntik 3 bulan yang telah menggunakan kontrasepsi minimal 3 bulan sebanyak 50 responden. Analisis data dilakukan secara bivariat menggunakan uji spearman rho. Hasil penelitian menunjukkan 22 aksseptor (44\%) mengalami efek samping berat dan sebagian besar mengalami efek samping setelah pemakaian kontrasepsi suntik DMPA > 3 bulan hingga 1 tahun (60\%). Terdapat hubungan ke arah positif dan signifikan antara lama pemakaian kontrasepsi suntik DMPA dengan timbulnya efek samping $(\rho=0,000<$ 0,05). Penelitian ini dapat disimpulkan bahwa timbulnya efek samping sangat dipengaruhi oleh lamanya penggunaan KB suntik DMPA.
\end{abstract}

Kata kunci : Lama Pemakaian KB Suntik DMPA, Timbulnya Efek Samping

\begin{abstract}
Side effect by injection contraceptive such as menstruation disorders, depressions, hair fall, acne, changes in libido, fluor albus, vomiting, headache, changes in weight, one of cause is duration of usage. It has an impact among others hormonal disorders, fertility disorders, chests of cholesterol due to fat deposits, infection, vaginal bleeding, fluor albus, client drop out. The purpose of this research was to determine the relationship between the old usage DMPA with side effects arise of contraception acceptor. This research used correlation analitic with cross sectional. Sample of this reseacrh was the acceptor DMPA who had used DMPA contraception 3 month ago as much 50 respondents. Bivariate date were analyzed using spearman rho test. The result showed 22 acceptors (44\%) get serious side effect and most of the respondent get side effect after using DMPA contraception more 3 month-1 year (60\%). Any positive relationship and significant between the old usage with side effect arise $(\rho=0,000<0,05)$. Thus it can be concluded that side effect of DMPA affected by the longer women used DMPA injection.
\end{abstract}

Keyword: The Old Usage, Side Effect Arise 


\section{PENDAHULUAN}

Keluarga berencana adalah usaha untuk mengukur jumlah dan jarak anak yang diinginkan. Agar dapat mencapai hal tersebut, maka dibuatlah beberapa cara atau alternatif untuk mencegah ataupun menunda kehamilan. Kontrasepsi termasuk cara pencegahan kehamilan dan perencanaan keluarga. Mewujudkan keluarga kecil sesuia dengan kekuatan sosial ekonomi suatu keluarga, melalui pengaturan kelahiran anak merupakan tujuan umum dari keluarga berencana. (Sulistyowati, 2012).

Indonesia termasuk negara berkembang di Asia Tenggara yang juga mengalami masalah kependudukan. Tingginya pertumbuhan penduduk, persebaran penduduk yang tidak merata, serta struktur umur muda dan kualitas penduduk yang perlu ditingkatkan (Hanifa, 2002). Jumlah penduduk 216 juta jiwa dan laju pertumbuhan penduduk 1,66\% THR 2873 atau 2,7 per wanita per tahun, maka saat ini sangat diperlukan penurunan laju pertumbuhan penduduk di Indonesia (Hanafi, 2003).

Kontrasepsi merupakan bagian dari pelayanan kesehatan reproduksi untuk pengaturan kehamilan dan merupakan hak setiap individu sebagai makhluk seksual (Sarwono, 2006). Kontrasepsi memiliki berbagai macam metode yaitu kontrasepsi sederhana, metode kontrasepsi efektif dan kontrasepsi mantap. Namun dari semua metode tersebut yang paling dianjurkan oleh pemerintah adalah metode kontrasepsi efektif. Metode kontrasepsi efektif diantaranya adalah KB pil, suntik, implant dan IUD (Hanafi, 2003). Kontrasepsi suntik adalah cara untuk mencegah terjadinya kehamilan dengan melalui suntikan hormonal (Harnawatiaj, 2008).

Pencapaian peserta KB baru terhadap PUS di Indonesia tahun 2015 sebanyak 13,46\% akseptor dengan angka efek samping peserta $\mathrm{KB}$ yang masih tinggi mencapai 50\% berasal dari kontrasepsi suntik (BKKBN， 2016). Akseptor KB dengan semua cara di Indonesia pada tahun 2015 antara lain suntikan $59,57 \%$, pil $20,71 \%$, kondom $1 \%$, MAL $0,11 \%$, Kalender 1,15, MOW $3,23 \%$, MOP 0,27\%, IUD 7,30\%, Susuk 6,21\%, lainnya $0,39 \%$ (Susnas, 2015). Akseptor KB di Jawa Timur sampai dengan Februari 2017 sebanyak 5.814.446 akseptor KB aktif, dengan pencapaian tertinggi pada KB suntikan sebesar $(37,26 \%)$, terendah pertama adalah kondom $(1,47 \%)$ serta dari kegiatan pelayanan kasus efek samping disebutkan bahwa kasus tertinggi dari peserta KB suntik yaitu sebesar 2.672 kasus $(54,8 \%)$, berikutnya peserta IUD sebesar 951 kasus $(19,5 \%)$, sedangkan kasus terendah terdapat pada peserta KB kondom $(0,0 \%)$ (Ditlap, 2008). Data peserta KB aktif metode IUD sebanyak 67.883 , suntik 138.611 , pil 112.861 , implan 36.368, MOW 9.357, MOP 714 (DinKes Jember, 2016).

Berdasarkan data yang diperoleh di PMB (Praktik Mandiri Bidan) Henry Wulandari, A.Md. Keb Desa Antirogo Kabupaten Jember peserta KB selama periode Maret 2018 sebanyak 1.601 akseptor dengan rincian peserta $\mathrm{KB}$ sesuai metode kontrasepsi antara lain : akseptor pil 38,28\%, IUD 4,55\%, Implan 11,4\%, suntik 42,5\%, kondom 2,06\%, MOW 1,12\%, MOP 
$0 \%$, hampir seluruhnya dari akseptor menggunakan KB suntik. Menurut Saifuddin (2005), dapat diketahui efek samping dari penggunaan KB suntik adalah amenorhoe, haid tidak teratur, spotting, sakit kepala, peningkatan berat badan, mual muntah, peningkatan tekanan darah. Berdasarkan hasil studi pendahuluan dari 20 peserta KB suntik 3 bulan, 5 responden mengalami spotting, 5 responden mengalami amenorhoe, 3 responden haidnya tidak teratur, 7 responden berat badan meningkat, serta dari terjadinya efek samping tersebut 3 responden menggunakan kontrasepsi selama 0-3 bulan, 13 responden menggunakan kontrasepsi selama 3 bulan -1 tahun, 4 responden menggunakan kontrasepsi selama 1 5 tahun. Hal ini menunjukkan pengaruh dari faktor hormonal mengakibatkan tingginya angka keluhan efek samping dari akseptor KB suntik berupa gangguan haid (amenorhoe, haid tidak teratur, spooting), pusing, pertambahan berat badan yang berkaitan dengan lama pemakaian kontrasepsi di PMB Henry Wulandari, A.Md Keb Desa Antirogo Kab. Jember.

Faktor penyebab dari timbulnya beberapa keluhan adalah lama pemakaian KB, jenis kontrasepsi, ketidakseimbangan hormonal dalam tubuh, peningkatan kadar lemak dalam tubuh (Hanafi, 2004). Dampak yang mungkin timbul dari keluhan tersebut adalah adanya gangguan hormonal, gangguan pada tingkat kesuburannya, penumpukan kolesterol akibat timbunan lemak serta dapat meningkatkan kecemasan klien, klien drop out dari program $\mathrm{KB}$ suntik, timbulnya rumor atau gosip yang berlebihan akibat penderitaan berkepanjangan, ketidakpuasan klien terhadap program KB suntik, muncul bahaya yang serius misalnya infeksi, perdarahan vaginal yang berat, perforasi dan keputihan berlebihan (DepKes, 2005).

\section{METODE PENELITIAN}

Penelitian ini merupakan jenis analitik korelasional yang menggunakan rancangan cross sectional untuk mengetahui apakah terdapat hubungan antara lama pemakaian kontrasepsi suntik DMPA dengan timbulnya efek samping pada akseptor KB di PMB Henry Wulandari, A.Md Keb Desa Antirogo Kab. Jember pada bulan Mei - Juni 2018.

Populasi pada penelitian ini adalah akseptor kontrasepsi suntik dan sampel penelitian ini adalah akseptor kontrasepsi suntik 3 bulan yang telah menggunakan kontrasepsi minimal 3 bulan. Besar sampel pada penelitian ini adalah 50 responden. Instrumen yang digunakan pada penelitian ini yaitu rekam medis KB dan data sekunder diperoleh dari kuesioner yang dibagikan pada responden di PMB Henry Wulandari, A.Md Keb. Desa Antirogo Kabupaten Jember. Teknik sampling menggunakan purposive sampling yaitu peneliti membuat pertimbangan tersendiri sesuai dengan ciri atau sifat populasi yang sudah diketahui sebelumnya (Notoadmojo, 2005). Pengolahan data melalui tahapan editing, coding, entry dan cleaning. Analisa data menggunakan analisis univariat pada karakteristik responden dan bivariat menggunakan uji spearman dengan SPSS dengan taraf signifikan $<0,05(\mathrm{p}=<0,05)$. 


\section{HASIL PENELITIAN}

Tujuan dari penelitian ini yaitu mengetahui hubungan lama pemakaian kontrasepsi suntik DMPA dengan timbulnya efek samping pada akseptor KB di PMB Henry Wulandary, A.Md Keb Desa Antirogo Kabupaten Jember, dengan hasil sebagai berikut:

\section{Karakteristik Akseptor KB Suntik DMPA}

Karakteristik akseptor berdasarkan umur sebagai berikut :

Tabel 1. Karakteristik Akseptor KB Berdasarkan Umur

\begin{tabular}{cccc}
\hline No & Umur (Tahun) & Frekuensi & Persen $(\%)$ \\
\hline 1 & $<20$ tahun & 4 & 8 \\
\hline 2 & $21-35$ th & 46 & 92 \\
\hline 3 & $>35$ tahun & 0 & 0 \\
\hline & Total & 50 & 100 \\
\hline
\end{tabular}

Karakteristik akseptor berdasarkan pendidikan sebagai berikut:

Tabel 2. Karakteristik Akseptor KB Berdasarkan Pendidikan

\begin{tabular}{|c|c|c|c|}
\hline No & Umur (Tahun) & Frekuensi & Persen $(\%)$ \\
\hline 1 & SD & 17 & 34 \\
\hline 2 & SMP & 20 & 40 \\
\hline 3 & SMA & 13 & 26 \\
\hline \multicolumn{2}{|r|}{ Total } & 50 & 100 \\
\hline
\end{tabular}

Karakteristik akseptor berdasarkan pekerjaan sebagai berikut:

Tabel 3. Karakteristik Akseptor KB Berdasarkan Pekerjaan

\begin{tabular}{cccc}
\hline No & Umur (Tahun) & Frekuensi & Persen $(\%)$ \\
\hline 1 & IRT & 40 & 80 \\
\hline 2 & Buruh & 3 & 6 \\
\hline 3 & Wiraswasta & 7 & 14 \\
\hline & Total & 50 & 100
\end{tabular}

\section{Analisis Univariat}

Lama pemakaian kontrasepsi suntik DMPA terlihat dalam tabel di bawah ini:

Tabel 4. Lama Pemakaian Kontrasepsi Suntik DMPA

\begin{tabular}{ccc}
\hline Lama pemakaian & Frekuensi & Persen $(\%)$ \\
\hline $0-3$ bulan & 10 & 20 \\
\hline 3 bulan-1 th & 30 & 60 \\
\hline$>1-5$ tahun & 10 & 20 \\
\hline Total & 50 & 100
\end{tabular}


Tabel 5. Timbulnya Efek Samping pada Akseptor KB

\begin{tabular}{ccc}
\hline Efek samping (ES) & Frekuensi & Persen $(\%)$ \\
\hline Ringan : 1-2 ES & 9 & 18 \\
\hline Sedang : 3-4 ES & 19 & 38 \\
\hline Berat : >5 ES & 22 & 44 \\
\hline Total & 50 & 100
\end{tabular}

\section{Analisis Bivariat}

Tabel 6. Hubungan Lama Pemakaian Kontrasepsi Suntik DMPA dengan

Timbulnya Efek Samping pada Akseptor Suntik

\begin{tabular}{lcccccc}
\hline & $\begin{array}{c}\text { Ringan } \\
(\mathrm{F})\end{array}$ & $\%$ & $\begin{array}{c}\text { Sedang } \\
(\mathrm{F})\end{array}$ & $\%$ & Berat $(\mathrm{F})$ & $\%$ \\
\hline $0-3$ bln & 1 & 12,5 & 6 & 31,6 & 5 & 21,7 \\
\hline$>3$ bl-1 th & 5 & 62,5 & 10 & 52,6 & 13 & 56,5 \\
\hline$>1-5$ th & 2 & 25 & 3 & 15,8 & 5 & 21,7 \\
\hline & 8 & 100 & 19 & 100 & 23 & 100 \\
\hline
\end{tabular}

Tabel 7. Hasil Analisis Menggunakan Uji Spearman:

Correlations

\begin{tabular}{|rll|r|r|}
\hline & & $\begin{array}{c}\text { Lama } \\
\text { Pemakaian }\end{array}$ & Ef ek Samping \\
\hline Spearman's rho & Lama Pemakaian & Correlation Coefficient & 1,000 &, $785^{* *}$ \\
& & Sig. (2-tailed) &. &, 000 \\
& $\mathrm{~N}$ & 50 & 50 \\
\cline { 2 - 5 } & Ef ek Samping & Correlation Coefficient &, $785^{* *}$ & 1,000 \\
& Sig. (2-tailed) &, 000 &. \\
& $\mathrm{~N}$ & 50 & 50 \\
\hline
\end{tabular}

${ }^{* *}$. Correlation is significant at the 0.01 level (2-tailed).

Berdasarkan analisis uji spearman rho sesuai tabel 7 didapatkan hasil bahwa nilai $\rho=0,000<0,05$, menunjukkan arah positif (+) dan signifikan. Hasil perhitungan tersebut menunjukkan bahwa Ho ditolak, artinya bahwa lama pemakaian kontrasepsi suntik DMPA mempunyai hubungan dengan timbulnya efek samping.

\section{PEMBAHASAN}

\section{Lama Pemakaian Kontrasepsi Suntik DMPA}

Berdasarkan hasil penelitian sesuai tabel 4 tentang lama pemakaian kontrasepsi suntik DMPA didapatkan hasil 30 responden $(60 \%)$ menggunakan kontrasepsi suntik DMPA selama >3bulan -1 tahun. Peserta KB suntik dikatakan baru adalah dengan masa pemakaian kontrasepsi suntik selama 0-3 bulan, pemakaian sedang selama >3bln1thn pemakaian lama selama $>1-5$ tahun. Umumnya pemakai KB suntik mempunyai persyaratan sama dengan pemakai pil, penggunaan cara KB hormonal selama maksimal 5 tahun (Harnawati, 2008). Semakin lama masa pemakaian KB suntik akan menimbulkan beberapa dampak baik 
secara langsung muncul ataupun dalam waktu yang lama, begitu pula bila masa pemakaian KB suntik yang tidak terlalu lama kemungkinan untuk mengalami dampak bagi tubuhnya juga semakin kecil.

Tingkat usia responden yang sebagian besar berusia 21-35 tahun yaitu sebanyak 45 responden (92\%), yang mana pada usia 21-35 tahun lebih memilih menggunakan kontrasepsi hormonal sehingga untuk timbulnya beberapa efek samping masih tinggi, selain itu dari faktor pekerjaan didapatkan setengah dari jumlah responden yaitu 17 responden $(50,0 \%)$ sebagai ibu rumah tangga yang dalam hal ini lebih berpikir praktis dan ekonomis dalam pemakaian kontrasepsi. Selain itu dari faktor pendidikan ibu hampir setengahnya yaitu 20 responden (40\%) adalah pendidikan SMP, yang mana hal itu berpengaruh pada keefektifan penerimaan informasi. Berdasarkan beberapa hal tersebut dapat mempengaruhi lama pemakaian KB suntik yang pada akhirnya diperoleh hasil bahwa masa pemakaian KB suntik masih dalam rata-rata waktu yang sedang (>3bulan-1 tahun).

\section{Timbulnya Efek Samping pada Akseptor KB}

Berdasarkan hasil penelitian sesuai tabel 5 tentang timbulnya efek samping didapatkan dari 22 responden (44\%) mengalami efek samping berat. Menurut DepKes RI (2005), efek samping KB suntik adalah hasil pengiring yang tidak diinginkan atau diharapkan dalam pemakaian KB suntik. Efek samping yang dapat timbul meliputi gangguan haid (amenorhoe, haid tidak teratur, spotting), perubahan berat badan, depresi, leukorhea, jerawat, pusing, mual dan muntah, perubahan libido, pengeroposan tulang. Kriteria efek samping ringan apabila mengalami 1-2 efek samping, sedang apabila mengalami 3-4 efek samping, berat mengalami $>5$ efek samping.

Hasil yang mana hampir setengahnya mengalami efek samping dapat dipengaruhi beberapa hal, diantaranya pada usia 21-35 tahun lebih memilih menggunakan kontrasepsi hormonal sehingga untuk timbulnya beberapa efek samping masih tinggi.

\section{Hubungan Lama Pemakaian Kontrasepsi Suntik DMPA dengan Timbulnya Efek Samping pada Akseptor Kb}

Berdasarkan hasil perhitungan dengan menggunakan uji spearman diperoleh hasil bahwa nilai $\rho=0,000<0,05$ maka Ho ditolak berarti ada hubungan antara lama pemakaian KB suntik dengan timbulnya efek samping pada akseptor KB. Hubungan lama pemakaian $\mathrm{KB}$ suntik dengan timbulnya efek samping berhubungan dengan perilaku kesehatan. Suatu respon seseorang (organisme) terhadap stimulus yang berkaitan dengan sakit dan penyakit, sistem pelayanan kesehatan dan lingkungan merupakan perilaku kesehatan. Unsur pokok yang terdapat di dalamnya yaitu respon dan stimulus atau perangsangan. Respon atau reaksi manusia, baik bersifat pasif (pengertian, persepsi dan sikap) maupun bersifat aktif (tindakan yang nyata atau praktis), sehingga timbulnya efek samping pada akseptor sangat dipicu oleh lamanya pemakaian kontrasepsi suntik. 


\section{SIMPULAN DAN SARAN}

\section{Simpulan} ini yaitu:

Kesimpulan dalam penelitian

1. Lama pemakaian kontrasepsi suntik DMPA di PMB Henry Wulandari, A.Md Keb sebagian besar responden masa pemakaian $\mathrm{KB}$ suntik dalam waktu sedang (>3bulan-1 tahun).

2. Timbulnya efek samping pada akseptor KB suntik hampir setengahnya responden mengalami efek samping berat (mengalami $>5$ efek samping).

3. Ada hubungan antara lama pemakaian kontrasepsi suntik DMPA dengan timbulnya efek samping pada akseptor KB di PMB Henry Wulandari, A.Md Keb dengan uji spearman rho didapatkan hubungan positif $(+)$ dan signifikan.

\section{Saran}

Berdasarkan hasil analisa dan kesimpulan, maka dikemukakan beberapa saran antara lain sebagai berikut :

1. Bagi Peneliti

Sebagai bidan yang profesional, hendaknya mempunyai pengetahuan dan kemampuan yang baik sehingga dapat memahami serta memberikan penyuluhan tentang kontrasepsi suntik.

2. Bagi Lahan

Diharapkan bagi petugas kesehatan dapat memberikan penjelasan tentang efek samping kontrasepsi suntik dan melakukan pengendalian terhadap pemakai kontrasepsi suntik dalam waktu yang lama.

3. Bagi Institusi Pendidikan
Diharapkan peneliti selanjutnya dapat melakukan penelitian dari faktor lain yang dapat meningkatkan target capaian penggunaan kontrasepsi suntik.

4. Bagi Responden

Diharapkan lebih aktif untuk mendapatkan penjelasan dari petugas kesehatan tentang waktu yang efektif dari pemakaian kontrasepsi suntik.

\section{DAFTAR PUSTAKA}

Arikunto, S. 2006. Prosedur Penelitian Suatu Pendekatan Praktek. Jakarta: Rineka Cipta

DinKes Kab. Kediri. 2006. Data akseptor KB. Kediri: DinKes Kab. Kediri.

Depkes RI. 2005. Pedoman Penanggulangan Efek Samping/Komplikasi Kontrasepsi. Jatim: Depkes.

Ditlap.2008.KB Suntik. Jakarta:BKKBN.http://www.bk kbn.go.id

Effendy.2008.kehumasan.Jakar ta:Depdagri.http://www.depdag ri.go.id/content.php?nama=keh umasan\&start $=2$.

Hartanto, Hanafi. 2004. Keluarga Berencana dan Kontrasepsi. Jakarta: Pustaka Sinar Harapan.

Hidayat, A. A. 2007. Metode Penelitian Kebidanan dan Teknik Analisis Data. Jakarta: Salemba Medika.

Harnawati.2008.kontrasepsi suntik.http://puskesmasoke.blogspot.com/2008/11/kont rasepsi-suntik.html. 
Jannati. 2015. Hubungan lama pemakaian alat kontrasepsi suntikan dengan gangguan siklus menstruasi pada akseptor KB di Puskesmas Peukan Bada kabupaten Aceh Besar. Simtakp.uui.ac.id/docjurnal/jan nati-jurnal.pdf.

Lestari. 2014. Hubungan antara lama penggunaan metode kontrasepsi hormonal dengan kejadian hipertensi. Jurnal ilmu keperawatan dan kebidanan Vol. 2 No. 1.

Manuaba, Ida Bagus Gde. 1999. Memahami Kesehatan Reproduksi Wanita. Jakarta: Arcan.

Munayarokh. 2014. Hubungan lama pemakaian kontrasepsi suntik DMPA dengan gangguan menstruasi di BPM Mariyah Nurlaili Rambe Anak Mungkid. Jurnal Kebidanan Vol. 3 No. 6 April 2014.

Nazir, M. 2003. Metode Penelitian. Jakarta: Ghalia Indonesia.

Notoatmodjo, S. 2002. Pendidikan dan Perilaku Kesehatan. Jakarta: Rineka Cipta.

Notoatmodjo, S. 2003. Ilmu Kesehatan Msyaarakat Prinsipprinsip Dasar. Jakarta: Rineka Cipta.

Notoatmodjo, S. 2005. Metodologi Penelitian Kesehatan. Jakarta: Rineka Cipta.

Nursalam. 2003. Konsep \& Penerapan Metodologi
Penelitian Ilmu Keperawatan. Jakarta: Salemba Medika.

Saifuddin, Abdul Bari. 2005. Buku Panduan Praktis Pelayanan Kontrasepsi. Jakarta: Yayasan Bina Pustaka Sarwono Prawirohardjo.

Saifuddin, Abdul Bari. 2006. Buku Panduan Praktis Pelayanan Kontrasepsi. Jakarta: Yayasan Bina Pustaka Sarwono Prawirohardjo.

Sugiyono. 2006. Statistik Untuk Kesehatan. Bandung: ALFABETA.

Sulistyawati, Ari. 2012. Pelayanan Keluarga Berencana. Jakarta: Salemba Medika.

Wiknjosastro, Hanifa. 2002. Ilmu Kebidanan. Jkarta: Yayasan Bina Pustaka Sarwono Prawirohardjo.

Zahera. Kenaikan berat badan dengan lama pemakaian alat kontrasepsi hormonal wilayah kerja Puskesmas pembantu Sungai Mengkuang tahun 2015. Journal endurance 1 (1) 22-27. 